\title{
THE SIMPLIFIED ASSET MANAGEMENT PLAN FOR A SUSTAINABLE FUTURE: INDONESIA'S IRRIGATION SYSTEMS
}

\author{
I. KUSTIANI \& D. SCOTT \\ Department of Civil Engineering, Curtin University, Australia.
}

\begin{abstract}
Agricultural irrigation plays a fundamental role in ensuring the food security and economy of rural communities. However, irrigation systems in many developing countries suffer from low performance, which eventually adversely affects their sustainability.

To gain a more in-depth understanding of performance and sustainability in existing Indonesian irrigation systems, a set of assessment was conducted. This incorporated methods of Rapid Appraisal Process and Benchmarking, an opinion survey, and an asset survey. A triple-bottom line (TBL) sustainability assessment was also conducted to determine the levels of sustainability and performance shortfall, as well as their causes. Based on the results, a set of physical and managerial changes were proposed to improve irrigation system performance and sustainability. The viability of the proposed changes was assessed further through a stakeholder's opinion survey and against three key sustainability issues of a TBL sustainability indicator framework: technical and economic, social, institutional and legal issue, and environmental, public health and safety. The purpose was to find an alternative and robust solution that was also preferred by stakeholders.

Eventually, a simplified asset management planning (AMP) model was developed, which would enable water user associations to implement independently and easily. The AMP, consisting of budget planning and short-term planning, was also based on the robust preferred priorities of improving irrigation performance and sustainability.

Keywords: Asset management planning, irrigation service fee, life cycle cost, water user associations.
\end{abstract}

\section{INTRODUCTION}

Irrigation plays an important role in the development of countries where agriculture is the main sector of the economy. According to the Food and Agricultural Organization (FAO), the world's irrigation systems produce $40 \%$ (by weight) or $60 \%$ (on a dollar basis) of the world's food supply, and crop production in developing countries is projected to increase $175 \%$ by 2030 . However, this increase will cause further sustainability issues for irrigation water and land. Decline in supply and condition of irrigation water and cropland is predicted to cause annual global losses of 350 million metric tonnes of food in 2025 [1].

For example, in Indonesia over the last 20 years it is estimated that 2.5 million paddy fields have been converted for other use, without an equivalent replacement, and water shortages during the dry season are becoming increasingly evident. Moreover, the biggest threat to irrigation is deferredmaintenance ageing and a lack of rehabilitation of irrigation assets, caused primarily by a lack of adequate funding. This has created severe constraints on performance, which results in low productivity. In turn, this threatens the sustainability of irrigation systems.

Improved irrigation performance and sustainability can be achieved through better asset management. Malano and Hofwagen [2] described irrigation asset management as: ' ... A strategy for the creation or acquisition, maintenance, operation, rehabilitation, modernisation and disposal of irrigation and drainage assets to provide an agreed level of service in the most cost-effective and sustainable manner'. Since the tertiary-level irrigation system operation and maintenance in Indonesia are being transferred to water user associations (WUAs), irrigation system performance and sustainability improvements are achieved through a participatory approach. Therefore, with regard to Burton et al. [3] opinion that stated the simplified asset management procedure for a 
transferred irrigation systems is a relevant and applicable procedure to the conditions experienced in a transferred irrigation system. The Asset Management Plan (AMP) model developed was a simplified one and that enables WUAs to manage the assets of a transferred irrigation system in the most cost-effective and sustainable manner. It is expected that this simplified AMP model could help not only WUAs in rural Indonesia to improve water and irrigation asset management but also could be implemented in other developing countries.

According to Burton et al. [3], a major component of AMP is the assessment of the current condition and performance of the irrigation system that is carried out through asset surveys as well as assessment of the desired level of service, which can be made through interviews and discussions with water users. Previous assessments on the irrigation system case studies by Kustiani and Scott [4] incorporated methods of rapid appraisal process (RAP) and benchmarking, opinion surveys, and asset surveys. It was intended to gain a more in-depth perspective on the existing Indonesian irrigation system. The results from these assessments were assessed further through a sustainability framework that identifies the objectives related to the Triple Bottom Line (TBL) sustainability (people, planet and profit). The TBL framework addresses these objectives using selected indicators and performance measures, and it became a complement to the previous assessments to review how well the system meets current and projected standards of service targets, without reducing natural resources.

The performance and sustainability assessments showed that the irrigation system case studies performance were typically below their potential and the condition of the assets was typical of deferred maintenance; it can be understood that the TBL sustainability assessment results showed that irrigation sustainability was at risk. However, the study also found that despite these conditions, farmers were mostly satisfied with the services they received from the irrigation authorities; but they also wished for better services and infrastructure. The study also reviewed the performance and sustainability shortfall and its cause analysis and indicated three managerial changes and three physical changes needed to be carried out in order to improve irrigation performance and sustainability. The proposed changes were also taking into account the changes suggested by experts Bruns and Helmi [5] and Burt [6] as follows:

1. Modernising irrigation systems: (a) Applying pressurised irrigation methods and recirculating the irrigation water to improve irrigation efficiency, (b) improving channel conditions and increasing the number of turnouts/offtakes to improve irrigation services and water distribution, and (c) expanding the scope of the irrigation service fee (ISF) by specifying water delivery services, installing suitable measuring devices to implement the ISF based on the volume of water used, and increasing the ISF to improve water use efficiency and to increase management, operation and maintenance (MOM) cost recovery.

2. Improving irrigation system management, procedures, and communication by improving participation in irrigation management: (a) diversifying agriculture and developing agricultural business, (b) expanding the role of WUAs as business organisation/enterprises, and (c) hand over secondary-level/larger systems to WUAs.

The options of changes were then asked to the stakeholders through a Pair-wise Comparison questionnaire as a basis for them to make choices on changes. The preferences on the proposed options vary between governments, consultants and contractors, and farmers (WUA heads). Subsequently, the results were used to weigh the proposed actions against three key sustainability issues of the TBL sustainability indicator framework: technical and economic, social, institutional and legal issue, and environmental, public health and safety. These key issues were then developed further into several 


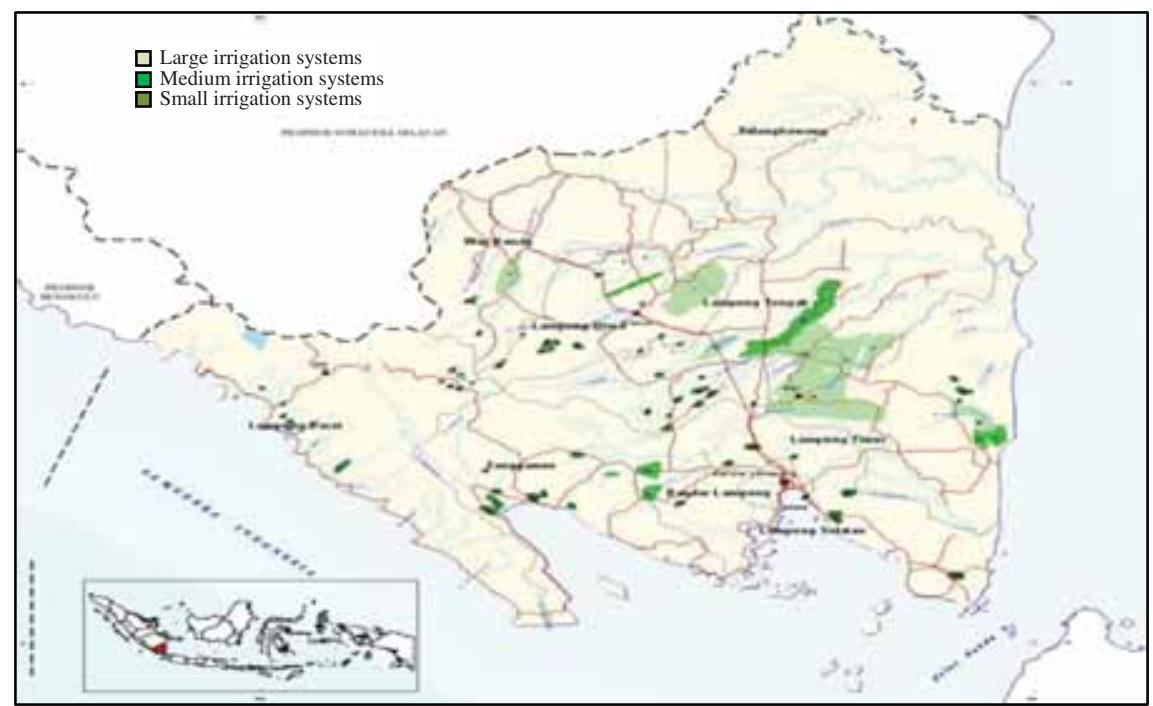

Figure 1: The sites of irrigation system case studies in the Province of Lampung (courtesy of Irrigation Authority, the Province of Lampung).

criteria for sustainability to determine the goals to be achieved in implementing the changes [7]. The purpose of the use and integration of these two methods was to find an alternative and robust solution that would be welcomed by stakeholders. The assessments showed that the physical changes that require major capital cost are less desirable as are managerial changes that would give WUAs greater authority.

Although modernisation of irrigation systems such as pressurised irrigation would improve efficiency and sustainability in terms of resources use and MOM, it is less desirable due to heavy costs along with restructuring of the MOM of irrigation systems.

The previous investigations on Indonesia irrigation system performance were mainly done in Java [8-12]. Just by looking at performance review of irrigation system in Java does not represent the performance of the majority of irrigation systems in Indonesia since it is widely known that irrigation systems (as well as WUAs) are well developed in Java and Bali. The Province of Lampung was chosen for some reasons, one of which is the province is one of the major rice production centres and a mainstay of regional food security. The research presents 11 case study irrigation systems (one large, three medium and nine small irrigation systems) scattered throughout the Way Seputih and Way Sekampung River catchment area in the Province of Lampung. Figure 1 illustrates the location of irrigation system case studies in the province and the location of the province in Indonesia.

\section{LITERATURE REVIEW}

AMP helps irrigation authorities utilise assets and maintain their condition in the best possible way to provide a level of service that is consistent with cost-effectiveness and sustainability objectives. AMP also assists in achieving the broad goals of system performance improvement [6]. AMP outcomes are designed to meet the requirements of reliability, manageability, financial viability and physical sustainability, and they must also meet equity, productivity and environmental requirements. Outcomes should also consider various constraints, prioritisation of alternative strategies, 
and sources and realistic levels of funding. The Institute of Irrigation Studies (IIS) [13] suggested that AMP contains a financial model with a provisional investment program consisting of capital planning (20 years), budget planning (5 years), budget priorities and investment priorities (5 years). For Indonesia context, the IIS suggested that the AMP should also include the elements of needsbased budgeting, ISF, turnover programs, efficient operation and maintenance, programming and monitoring systems, integrated basin water resources management, project benefit monitoring and evaluation, and cost-effective rehabilitation and modernisation system research study.

In the last two decades, the transferring of irrigation management from the government to user groups (WUAs) has been adopted by many countries. A study by Sampath [14] justified that improved water control/irrigation can be achieved at a comparatively low cost through local initiatives, responsibility and control. Therefore, devolving financial autonomy for operation and maintenance $(\mathrm{O} \& \mathrm{M})$ to user groups is advisable. The transfer requires communication between irrigation authorities and WUAs. Standards of performance measures and desired levels of service must be stipulated in order for WUAs to focus on sustaining and enhancing the condition of the irrigation infrastructure [3].

Turnover means that the government continues to operate dams and regulate river flows while the operation, management and water distribution lie with the farmers. It becomes the WUAs' responsibility to allocate water amongst its members and to recover the charges to permit longer term investments. This solution could resolve the O\&M problems with public irrigation systems. At the moment, the general consensus among governments and financial institutions is that the user should pay all the O\&M costs, and as much as possible of the capital costs.

According to Koç [15], financial administration of MOM services in irrigation systems is one of the most important functions of a WUA. To ensure the successful implementation of this program, the government should provide a simplified system to match local capability and resources. Proper financial management not only enables the WUA to properly operate and maintain its irrigation drainage system but also assures the economic viability and sustainability of the WUA, and establishes and maintains member confidence [16]. Aspects of the financial performance of irrigation that most relate to management transfer are the cost of irrigation to the government, the cost of irrigation to farmers, level of management staff (often the largest component of MOM costs, level of water charges and collection rates, budget solvency and revenue sources [17]. A study by Oad [18] suggested that a strong WUA is an excellent indicator and predictor of improved O\&M performance.

The price of water (ISF) is the amount paid for water consumption by the user. The purpose of the ISF, in accordance with Gerhard [19], is to enable the irrigation system to deliver water to all tertiary units in an equitable manner, to dispose of drainage water in a timely manner, and to facilitate the distribution of water. Water pricing methods vary considerably across and within the developing countries. There are many conflicting goals inherent in charging for water [20]. Vermillion and Johnson [21] proposed considerations such as area, volume and output basis choices in order to establish a workable ISF rate.

Public irrigation water prices are often determined by the amount needed to recover the cost of O\&M of irrigation projects, at the very least. Unfortunately, in many irrigation systems in developing countries, water is still provided as a free service or pricing systems act mostly as a disincentive to efficient water use. Moreover, many Asian countries have failed to make the necessary policy changes required to recover the costs of their irrigation systems [14]. Environmental degradation due to the inefficient utilisation of water is an example of the failure to recognise the value of water. Water pricing has to be accompanied by greater accountability and it should include the experience of the 'the farmer's voice'. Therefore, WUAs are a mechanism for introducing user incentives and they can play a key role (rights and responsibilities) in the management of small or tertiary-level 
irrigation systems. The ISF needs to be established at the tertiary level, for use by WUAs in supporting tertiary O\&M activities. ISF collection should generate funds and allocate them for the effective operation and maintenance of transferred irrigation systems.

There are three alternative asset management approaches suggested by the Australian Asset Management Collaborative Group [22]:

1. Option $A$ - The annual maintenance costs are low, but the annual capital costs are relatively high. This scenario could be expected in a situation where maintenance costs come out of a local revenue budget but capital costs are centrally controlled.

2. Option $B$ - The annual maintenance costs are high in order to prevent the deterioration of assets, but the annual capital cost of sustaining the standard of service (SOS) is low. This scenario could be expected in a situation where it is difficult to justify replacement expenditure, or where the prioritisation system favours improvement projects.

3. Option $C$ - Minimises the whole-life cost of providing the required SOS (i.e. the optimum balance between maintenance and replacement costs). This scenario is most likely in an organisation that is operating with effective asset management with clear responsibilities for whole-life costs, and sound information systems to support the best asset management decisions based on the whole-life cost.

Up until now, WUAs have been following Option A. However, the turnover of tertiary-level irrigation systems to WUAs means that WUAs are now fully responsible for MOM costs at this level. To successfully manage tertiary irrigation assets, WUAs must use the Option C approach. This option helps WUAs to ensure, where possible, that available funds are spent on planning, purchasing and installation, O\&M, and renewal of tertiary-level irrigation assets in a costeffective manner.

A formal asset management system/strategy (AMS) should also provide information on asset condition or performance. The Modern Equivalent Asset (MEA) is a common method, widely utilised to value assets. MEA value is the cost, at current prices, of a modern asset of equivalent function, not necessarily replicating the existing asset in precise detail. The gross MEA value is the full amount needed to provide such an asset at the current time. The net MEA value allows for the depreciation of asset value over its life. A relationship between the condition of an asset and its nominal depreciated value must be determined for use within the cost model [13]. In appraising the MEA value, discount rate and net present value principles are applied.

The results of the models are typically necessary to obtain approval to proceed. Life cycle cost (LCC) is the main tool used for the economic evaluation of public projects such as irrigation. LCC analyses and estimates total costs experienced in annual time increments over the life of an asset, including cost of acquisition, operation, maintenance, conversion/upgrade/renewal, and decommission with consideration given to the time value of money. The objective of LCC analysis is to choose the most cost-effective approach from a series of alternatives in order to achieve the lowest longterm cost of ownership. The process involves weighing the total expected costs against the total expected benefits of one or more actions and adjusted to account for the time value of money (present value). To derive a formulation for the LCC, it is important to develop a realistic estimation on the useful life of an asset and its depreciation, and its salvage value. LCC also requires appropriate records of past expenditure and asset condition over time. Unfortunately, the WUAs in Indonesia were still not aware of the importance to keep such information. Therefore, a typical deterioration curve for channels and hydraulic structure asset groups can be utilised to estimate future expenditure on assets. 


\section{METHODOLOGY}

A simplified AMP for sustainable Indonesian irrigation systems was developed over several stages by utilising and adapting several methods that have been internationally accepted. The stages of developing a simple and cost-effective AMP for rural irrigation systems were depicted as shown in Fig. 2. The Stage 1 and Stage 2 results have been published previously [4]; therefore, this paper only discusses the Stage 3 of the research.

The final stage aimed to develop an appropriate AMP that would enable WUAs in rural Indonesia to manage the assets of a transferred irrigation system in the best/most cost-effective way in order to achieve sustainability goals. An AMP for sustainable future Indonesian irrigation systems was developed by considering constraints, prioritising alternative strategies, and looking at sources and realistic levels of funding.

The simplified AMP model for a transferred system was developed based on the most robust physical and managerial proposed changes and by considering the aspects of budget constraints, and sources and realistic levels of funding. The financial modelling process (LCC) is one of the reviewing and refining provisional investment programs presented in the AMP. To derive a formulation for the LCC, the following assumptions were used: a useful life period of 25 years was set for the tertiary irrigation assets under evaluation [13] and a $15 \%$ discount rate was applied based on the Indonesia inflation rate for the last 22 years [23]. Since maintenance and renewal activities of assets at the tertiary level were not recorded, the assumptions made on asset condition was based on Stapelberg [24]: roughly a $40 \%$ drop in asset condition within $75 \%$ of useful life and a further $40 \%$ drop in condition (i.e. an $80 \%$ drop) within $80 \%$ of its useful life.

The objective of LCC analysis is to minimise the whole-life cost of providing the required SOS (i.e. the optimum balance between maintenance and replacement costs). A historical record of past expenditure, coupled with a forecast of expenditure to sustain the SOS, is a solid foundation to establish LCC. The future level of service was defined based on the previous assessment results [4] that showed the potential of irrigation system case studies. Therefore, the AMP is primarily used to communicate information about assets and the actions required to provide a defined level of service.

\section{DISCUSSION}

Since the province of Lampung experiences high and heavy rainfall, the potential for resourcing surface water and groundwater is great. Most of the region experiences its wet season for $9-10$ months a year. During the wet season, December to March is generally the first cropping season of rice; water availability is not a problem in most systems and is of a supplementary nature only. The second cropping season occurs from March to June, and although there is rain, optimal harvest achievement is required with the support of irrigation water. In some areas where irrigation water is adequate, a third cropping season can take place by growing a second crop (palawija) during the dry season. Therefore, water availability is an important factor that affects the level of services provided to the farmers in the second and third cropping season.

Irrigation water in the areas under study generally relies on supplies from the river run-off. Surface water supplies the rice fields by gravity-open channel networks that are generally unlined. There is no groundwater used in any of the case study irrigation systems.

At the moment, the Government of Indonesia is implementing a policy that empowers and strengthens WUAs by instituting a system that formally and legally recognises the rights of WUAs to manage public water and to collect ISFs for the water provided, and expanding the role of WUAs as business organisations. WUAs as business organisations are able to use profits from sideline activities to maintain financial stability and to cover their costs in the face of constantly increasing expenditure levels. 


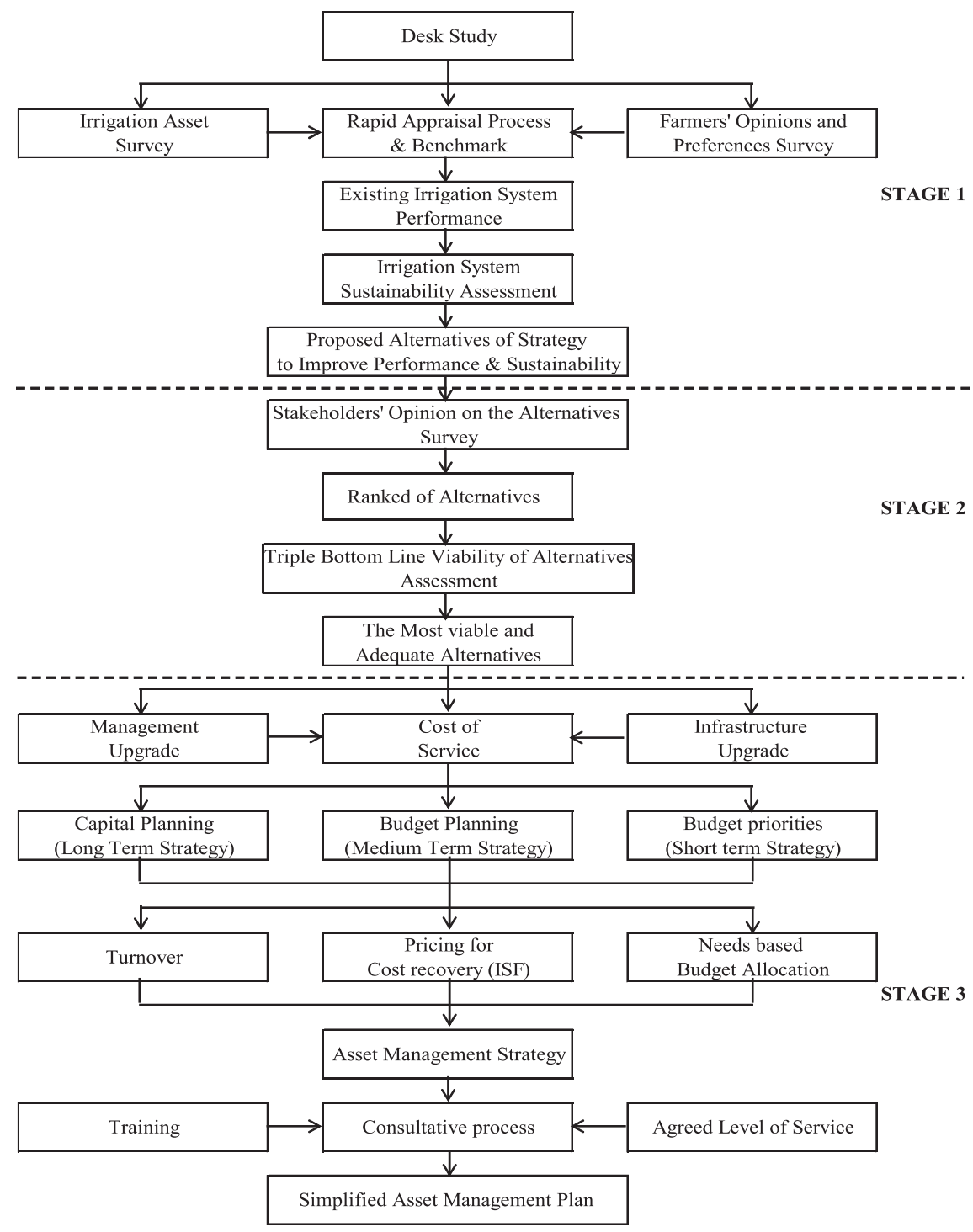

Figure 2: Improved process of developing AMP. Developed from Kustiani and Scott [4].

Irrigation infrastructure is financed by the Government and at the tertiary level, it is financed in collaboration with beneficiaries through a cost-sharing system. The strategy aims to develop WUAs technically and financially enough to become self-sufficient. WUAs would also be responsible for the O\&M of irrigation infrastructure and farmer investment in irrigation infrastructure by regulating water rights, taking into account water availability and water use efficiency. Unfortunately, only a few WUAs are financially and technically independent. Through Participatory Irrigation Sector Project (PISP), WUAs in the irrigation system case studies can be assisted to achieve financial and technical sustainability. 
Table 1: Rehabilitation cost/ha and tertiary work spent by PISP.

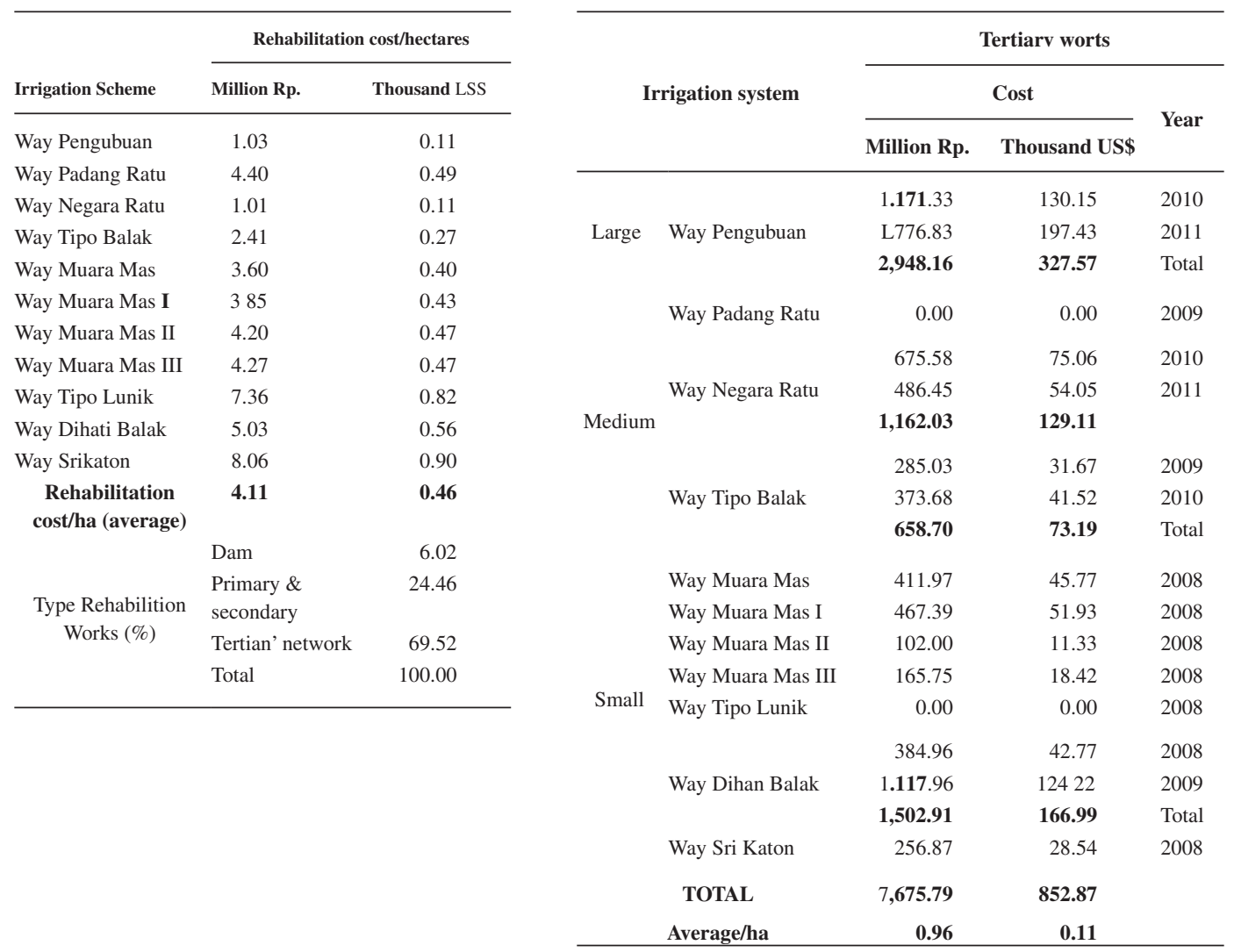

Source: The Government of the Province of Lampung, the Public Works Unit and PISP Implementation Unit [26]

PISP was implemented from 2005 to 2012. The PISP funded the rehabilitation works of tertiary level of irrigation system case studies, which was designed to ensure that the deferred maintenance cycle is broken and that irrigation systems performance is maintained at or close to the original design level. The projects also facilitated the growing need for the Participatory Irrigation Management approach. It is expected that the involvement of WUAs in project-funded rehabilitation will enable financial independence [25].

It can be seen from Table 1 that the average rehabilitation cost of the case study irrigation systems spent by the government through PISP was US\$460/ha (average provision spent on the tertiary level was US $\$ 110 /$ ha). In total, the project spent US $\$ 0.85$ million on these tertiary works over 5 years.

Historically, water in Indonesia has been provided as 'free goods' for agricultural purposes. At the moment, the ISF is established at tertiary level and it aims to generate and allocate sufficient funds for use by WUAs to properly support tertiary O\&M activities. Each WUA is able to decide on the charge to be levied on its members. The ISF is established on a seasonal basis according to the area irrigated, with no distinction between cropping seasons. In the province of Lampung, the rates vary from 50 to $60 \mathrm{~kg} / \mathrm{ha}$ (on average, $0.84 \%$ of their income is based on the 2009 farm gate unhulled rice selling price) or approximately US\$22.22 per ha. Collection rates are almost $100 \%$. The majority $(60 \%)$ of the tariff revenues are used to fund WUA activities and seasonal labour (controllers of 
water distribution (Ulu-Ulu and ili-ili), collectors of the ISF, and administrative costs), $20 \%$ is allocated to cover maintenance costs, and the remaining $20 \%$ is retained to cover unexpected cost events and office overhead. The ISF provision of $20 \%$ used to maintain the asset is not adequate to maintain the condition of asset at its best.

Table 2 shows that the portion of the ISF, i.e. $20 \%$ (US $\$ 0.35$ million), used by WUAs to fund the maintenance of tertiary works is only half the amount of that spent by the PISP to rehabilitate the tertiary networks. Since 1990, the cost of O\&M (operations and maintenance) has been found to be inadequate, resulting in decreased performance of the irrigation network.

The level of service is the extent or degree of service provided by an asset, based on and related to the operational and physical characteristics of that asset. The level of service is divided into the level of service of irrigation and drainage, the level of service of irrigation assets including conveyance (channel, hydraulic, and supplementary) structures, operation and controlling facilities, and the management and general facilities of tertiary-level irrigation systems. Basically, the level of service of irrigation at a tertiary level provided by WUAs/WUAFs requires a supply of irrigation water that is equitable, is of sufficient quantity, frequency, flow-rate, time, and duration. The level of service of tertiary-level irrigation systems is highly dependent on the level of service of irrigation at levels above this (at the source and secondary levels). The level of service should answer the increasing demand for water in the future, which requires on-going reviews of the ability of irrigation systems to meet such demand. Table 3 presents the possible future demands on the irrigation system case studies that were based on the results of performance and sustainability assessments [4].

Since at tertiary levels, financially autonomous WUAs are responsible for irrigation, future asset management and operations requirements should be their responsibility. This is particularly important over the next 5 years, as the irrigation systems will not receive any project funding from the Government, as is the nature of the project cycle in Indonesia. The amount spent by the project could be used as a guideline over the next 5 years to estimate the amount needed to rehabilitate at the tertiary level. This estimation has to be adjusted to the rate of inflation over the useful life of assets for projected whole-of-life costs.

Preparation of needs-based budgets, in line with the proposed changes, assists in ensuring that WUAs conform to budgets. Under the short-term budget framework, WUAs expenditure management is directed towards increasing performance while sustaining natural resources and alleviating economic pressure on farmers. Major challenges for WUAs in the short-term are to ensure uninterrupted water supply, finance tertiary irrigation MOM, and increase WUA member welfare. Increasing WUA responsibility (authority) does create huge pressure on WUA expenditure management. Therefore, there is an obvious need to formulate a proper financial management framework that encourages WUA initiatives in meeting administrative requirements. Furthermore, WUAs need to find a way to remove their dependence on government subsidies by increasing the ISF or the portion of ISF for maintenance.

Unfortunately, it is not easy to impose a higher ISF upon farmers. Despite the small ISF, most of the farmers remain poor because they can only cultivate landplots of 0.5 ha on average, which only generates a monthly income of US\$95.40. This amount only meets about half the needs of the average farmer, if there is no disruption to the harvest.

To successfully manage tertiary irrigation assets, WUAs must use the Option C approach. Option $\mathrm{C}$ helps WUAs to ensure, where possible, that available funds are spent on planning, purchasing and installation, O\&M, and renewal of tertiary-level irrigation assets in a cost-effective manner.

The AMP includes allowance for the provision of the basic function of supplying water from tertiary-level irrigation systems. The assets at the tertiary level of case study irrigation systems consist mainly of conveyance facilities (channels and hydraulic assets), and operation and controlling 


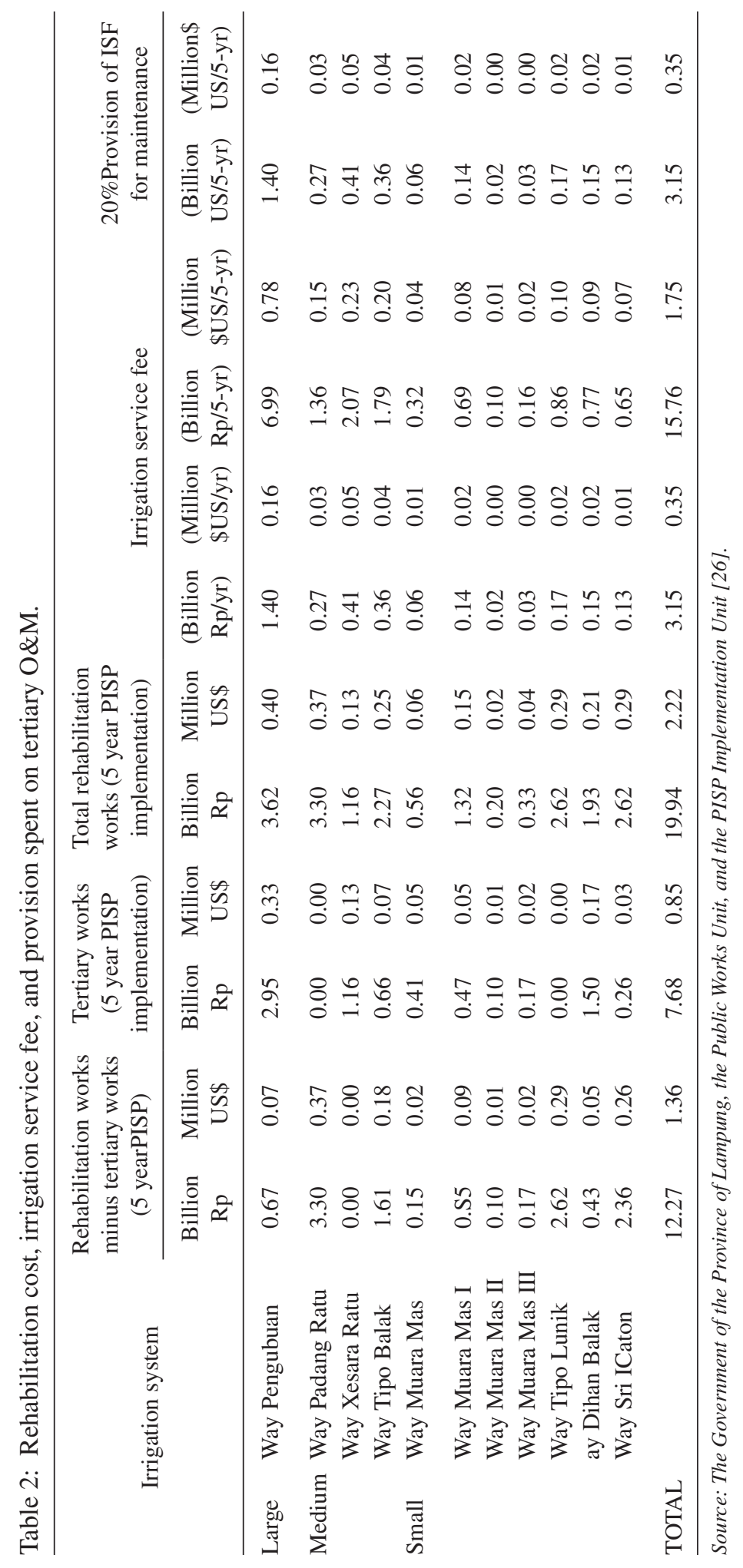


Table 3: Future projections on demand on the irrigation system case studies.

\begin{tabular}{|c|c|c|c|}
\hline Demand factor & Present position & Projection & Impact on services \\
\hline Command area & $8,066.00$ & $10,807.00$ & Greater demand \\
\hline Cropping intensity & 2.03 & 3.00 & Greater demand \\
\hline Supply of water & $\begin{array}{l}\text { No water restriction } \\
\text { (water distribution } \\
\text { rotation only), no } \\
\text { volume measurements }\end{array}$ & $\begin{array}{l}\text { Decreasing availability } \\
\text { of water resource } \\
\text { and increased costs } \\
\text { of service (there is } \\
\text { imperative to metering }\end{array}$ & $\begin{array}{l}\text { Greater irrigation awater } \\
\text { efficiency and require the } \\
\text { review of water charges to } \\
\text { cover the MOM costs }\end{array}$ \\
\hline Farmers' need & $\begin{array}{l}\text { Monoculture of rice } \\
\text { and second crops in } \\
\text { the dry season }\end{array}$ & $\begin{array}{l}\text { Diversifying } \\
\text { agriculture }\end{array}$ & $\begin{array}{l}\text { Greater flexibility in } \\
\text { water supply services } \\
\text { to satisfy and match } \\
\text { complex demands for } \\
\text { irrigation water as a }\end{array}$ \\
\hline \multirow{2}{*}{$\begin{array}{l}\text { Improving channel } \\
\text { conditions and } \\
\text { increasing the } \\
\text { number of turnouts/ } \\
\text { offtakes }\end{array}$} & $\begin{array}{l}\text { Only part of tertiary } \\
\text { channels are concrete }\end{array}$ & $\begin{array}{l}\text { Increase the length of } \\
\text { concrete lining }\end{array}$ & \multirow{2}{*}{$\begin{array}{l}\text { Increase conveyance } \\
\text { efficiency, improve } \\
\text { irrigation service and } \\
\text { water distribution }\end{array}$} \\
\hline & $\begin{array}{l}\text { Insufficient number } \\
\text { of turnouts/offtakes }\end{array}$ & $\begin{array}{l}\text { Increase the number of } \\
\text { turnouts/offtakes }\end{array}$ & \\
\hline \multirow{2}{*}{$\begin{array}{l}\text { Increase the length } \\
\text { of drainage chan- } \\
\text { nels }\end{array}$} & \multirow{2}{*}{$\begin{array}{l}\text { Only } 2 \text { of the } \\
\text { irrigation system } \\
\text { case studies have } \\
\text { drainage channels }\end{array}$} & \multirow[t]{2}{*}{$\begin{array}{l}\text { All irrigation systems } \\
\text { have drainage channels }\end{array}$} & $\begin{array}{l}\text { Minimize impact on the } \\
\text { river/environment }\end{array}$ \\
\hline & & & $\begin{array}{l}\text { Greater efficiency by } \\
\text { circulating irrigation } \\
\text { water in the fields to }\end{array}$ \\
\hline $\begin{array}{l}\text { Effluent } \\
\text { reuse/recirculate } \\
\text { irrigation water }\end{array}$ & $\begin{array}{l}\text { Currently all the } \\
\text { irrigation system } \\
\text { case studies are } \\
\text { discharging its } \\
\text { drainage water to the } \\
\text { natural water bodies/ } \\
\text { rivers }\end{array}$ & $\begin{array}{l}\text { Circulate irrigation } \\
\text { water is meant to prevent } \\
\text { fresh water as much as } \\
\text { possible discharged into } \\
\text { the river and preventing }\end{array}$ & $\begin{array}{l}\text { Greater efficiency to } \\
\text { conserve water }\end{array}$ \\
\hline
\end{tabular}

facilities (regulators) that are attached to channels. There is a direct link between the O\&M costs of an asset and the level of utilisation of an asset. By combining data, the cost per unit of service (i.e. asset service cost) can be calculated. The cost components of the irrigation system case studies are:

\section{Capital investment activities}

The costs associated with the works undertaken to rehabilitate, upgrade, extend, or improve existing system infrastructure. However, WUAs have not yet been able to utilise the ISF to fund capital investment. According to Small et al. [27], the capital cost in 1986 for small irrigation systems was US $\$ 8,000$, and for medium and large systems were US $\$ 1,500$ and US $\$ 3,000$, respectively. At present value, this corresponds between US $\$ 2,004$ and US $\$ 4,000$. Assuming the cost of capital needed for irrigation system case studies is US\$2,000, this was deployed into an annual cost over 25 years of US $\$ 80$. 
2. System operating costs

The aim of mapping the cost of operation is to gather as many elements of cost as possible that go into the operation of a system, to identify the possible gains with the current operational setup and service, and to know the cost of improved service implementation. For irrigation system case studies, the operating cost is mainly the cost of personnel since all assets are operated manually and a single WUA manages a local tertiary-level irrigation system; therefore, transport costs do not apply. Based on $60 \%$ of ISF collected were used for personnel, the operation costs have been calculated at US\$26/ha/year.

3. Maintenance costs

This refers to the costs of recording irrigation system operations over time, with a particular pattern of capital investment apparent when looking at deteriorating assets. Past maintenance records enable observation of trends in operating expenditure (OPEX). Unfortunately, no historical data on routine maintenance could be found, and replacement and renewal activities of assets at the tertiary level were not recorded. Table 2 shows that the average routine maintenance cost accounted for $20 \%$ of the collected ISF or US $\$ 9 /$ hectares/year. Therefore, the O\&M costs were US $\$ 35 /$ hectare/year. In 1998, it is estimated that the average budgetary requirement for maintenance of Indonesia's public irrigation systems was $\$ 18-28 /$ ha [28], which is equal to US $\$ 47 /$ hectare. Therefore, the current O\&M of US $\$ 35 /$ hectare is insufficient to meet service requirements and needs to be increased to US $\$ 73 /$ hectare.

4. Replacement costs

Various assets (or components of assets) have different useful lives and different maintenance requirements. Deterioration is regularly addressed with maintenance expenditure. Since there was no historical data on assets replacement, therefore, the deterioration curve for channels and hydraulic structure asset groups was assumed to follow the trend in Fig. 3. Replacement and renewal activities of tertiary assets are required when the condition of assets deteriorates between $25 \%$ and $60 \%$ of their original condition, and this usually occurs when assets reach $75-80 \%$ of their useful life. This means that rehabilitation works are needed when the age of assets reaches 16 to 20 years (in 2016). Table 1 shows that the rehabilitation costs for tertiary assets were US\$106/hectare. Assuming that rehabilitation costs are deployed over 20 years, then the rehabilitation cost required annually would be US $\$ 5$.

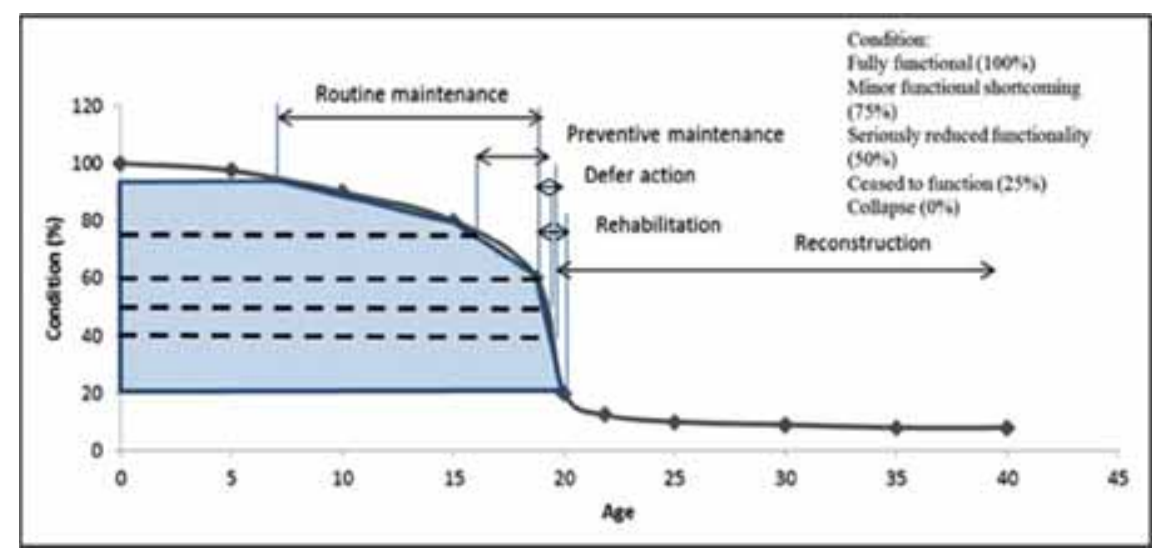

Figure 3: Typical deterioration curve for channels and hydraulic structure asset groups (adjusted from Stapelberg [24]). 
Table 4: The costs of service.

\begin{tabular}{ll}
\hline Cost of service in 2011/hectare/year & US\$ \\
\hline Capital cost & 80 \\
Routine O\&M & 73 \\
Replacement & 5 \\
Cost of service/ha/year & 158 \\
\hline
\end{tabular}

Table 4 shows a summary of the service costs for the tertiary irrigation system case studies. If the costs are to be recovered by the end of its useful life, the current ISF of US $\$ 44 /$ hectare/year ( $1 \%$ of farmer income) needs to be adjusted to maintain the condition of tertiary-level irrigation systems. The cost of services (US\$131) is still reliable, it accounts for $2.5 \%$ of farmer income. This amount is still far below the ISF imposed in other countries [28]. The ISF also needs to increase every year to adjust for inflation.

5. Depreciation: In the economic analysis of a project, depreciation should be considered. The simplest way to calculate depreciation is to utilise a straight-line method, in which an asset's condition depreciates uniformly over time. Since the useful life of an asset is considered to be 25 years [13], then the assets will depreciate at a rate of $4 \%$ per year.

6. Inflation rate and discount rate

Based on data obtained from the Bank of Indonesia [23], the inflation rate has fallen since 1990. This is due to sound economic growth and the current stable political condition in Indonesia. The latest records from the Bank of Indonesia show an inflation rate of 4.9\%. However, in the past Indonesia has experienced economic distress and very high inflation rates occurred during the global economic crisis in 1998. It is, therefore, difficult to estimate future inflation rates. The rate of inflation used in this report is 10\%, even though the trend line in Fig. 4 suggests a lower rate. The rate of discount is the desired profit margin, and this depends on the risks and uncertainties of a project. This means that the discount rate may be slightly higher than the costs that were incurred. The agricultural business sector (agribusiness) is one of the greatest in Indonesia, but crop production is dependent on global climate change; therefore, a discount rate of $15 \%$ should be applied. The following are the discount rate applied in the Philippines (15\%), India and Pakistan (12\%), and by the World Bank and Asian Development Bank (10 - 12\%) [29]. The inflation rate in Indonesia within the last 25 years is shown in Fig. 4.

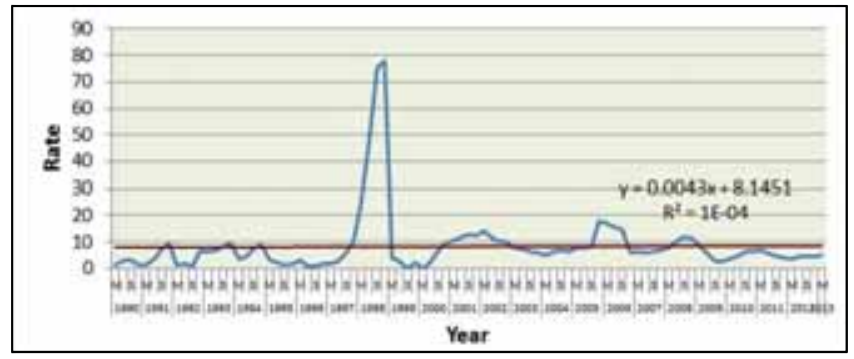

Figure 4: Indonesian inflation rate changes between 1990 and 2013 [23]. 

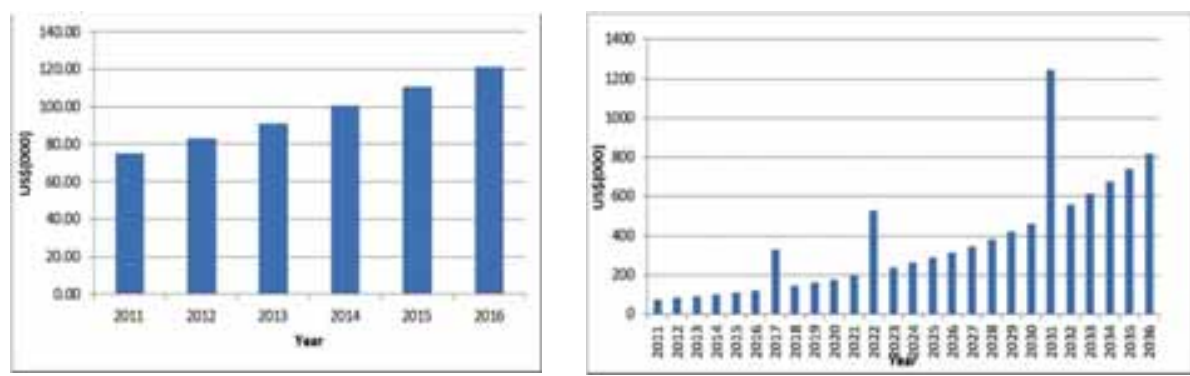

Figure 5: (a) Short-term maintenance planning and (b) medium and long-term planning (excluding implement pressurised irrigation methods and recirculate irrigation water) for the Way Padang Ratu irrigation case study.

Based on the above assumptions, tertiary routine $O \& M$ and rehabilitation costs for each irrigation system case studies can be projected and subsequently a simplified-sustainable and cost-effective AMP model can be developed. The following are the examples of AMP framework of the Padang Ratu irrigation system:

1. Budget planning (5 years): routine MOM costs:

Figure 5 shows an example of short-term maintenance planning for the Padang Ratu irrigation system.

2. Short-term planning (investment priorities, 5 years): Improve channel conditions and networks, and increase the number of turnouts/offtakes to improve irrigation services and water distribution. However, to be able to implement this program, WUAs have to previously solve the problem of funding. If the funds will be source from ISF, then it is necessary to consult with the farmer water users so that they are willing and able to bear the corresponding increase in ISF calculated above.

For medium and long-term capital planning, as outlined below, government involvement is a necessity.

3. Medium-term planning (capital planning, 10 years): Install suitable measuring devices to implement the ISF based on the volume of water used, raise the ISF to improve water use efficiency and to increase cost recovery.

4. Long-term planning (capital planning, 20 years): Implement pressurised irrigation methods and recirculate irrigation water to improve irrigation efficiency.

\section{CONCLUSIONS}

The AMP model developed was expanded by the IIS [13], and Burton et al. [3] discussed regarding simplified asset management planning for irrigation system in developing countries. The AMP was also developed by considering as much as possible the input from experts and organisations discussed in the literature review as well as secondary data from the PISP implementation. It could be expected that the simplified AMP developed in this study provides an appropriate way of running irrigation systems in an efficient, cost-effective and sustainable way and can be used by any owner/ user organisation such as WUAs which do not have any previous experience in running MOM asset of irrigation system. It also helps them to focus their efforts on achieving an improved irrigation system performance and sustainability. 
To ensure that the simplified AMP is successfully used by WUAs, it requires government assistance to provide technical support such as training and promoting effective and viable user associations as well as appropriate legal enforcement, government legislation and regulation in place. The results also indicate that successful implementation of the improved AMP may take several years but with positive long-term sustainable benefits. At the moment, the WUAs are only just ready to fund the MOM costs of tertiary-level irrigation system. If budget and short-term planning by farmers is successfully achieved, greater responsibility can be allocated to farmers in the future. The research suggests that to enable them to make physical improvements on physical assets, they need to generate income from sideline activities of the WUAs or increase the ISF. It could be expected that the outcome of this research would be useful for those formulating the viable option to facilitate more efficient use of irrigation resources and cost-effectiveness in the MOM of irrigation assets.

In the future, a more rigorous and compelling research methods should be carried out to assess the real impact of the simplified IMP as well as a review on the capacity and effectiveness of WUAs as business organisation in carrying the MOM of tertiary level of irrigation system not only in Indonesia but also in other countries with similar arrangement as Indonesia.

\section{REFERENCES}

[1] FAO, World agriculture: Towards 2015/2030, Summary report, Food and Agriculture Organization of the United States, 2002.

[2] Malano, H., \& P.V. Hofwegen., Management of Irrigation and Drainage Systems: A Service Approach, IHE Monograph 3. A.A. Balkema/Rotterdam/Brookfield, 1999.

[3] Burton, M. \& Newcombe, W. et al., Development and application of simplified asset management procedures for transferred irrigation systems. Irrigation and Drainage Systems, 17(1-2), pp. 87-108, 2003. doi: http://dx.doi.org/10.1023/A:1024948717975

[4] Kustiani, I. \&Scott, D., Developing an asset management plan for a sustinable future Indonesia irrigation systems. WIT Transaction on Ecology and Environment, 168, pp. 323 337, 2012, available at www.witpress.com, ISSN 1743-3541 (on-line). doi: http://dx.doi. org/10.2495/SI120281

[5] Bruns, B. \& Helmi, Participatory irrigation management in Indonesia: lessons from experience and issue for the future, World Bank and the FAO, 1996.

[6] Burt, C.M., Rapid Appraisal Process (RAP) and benchmarking: Explanation and tools, FAO, 2002.

[7] Ilemobade, A. \& Adewumi, J. et al., Framework for assessing the viability of implementing dual water reticulation systems in South Africa. Water S.A., 35(2), pp. 216, 2009.

[8] Johnson, SamIII, H. \& Reiss,P.,Can farmers afford to use the wells after turnover? A study of pump irrigation turnover in Indonesia, Short Report Series on Irrigation Management Transfer, No. 1, International Irrigation Management Institute, Colombo, 1993.

[9] Vermillion, D.L. \& Samad, M. et al., An assessment of the small-scale irrigation management turnover program in Indonesia, International Water Management Institute Research Report 38, 1999.

[10] FAO of the UN, Information and reporting system for water and agriculture in Asian monsoon areas: Performance analysis of paddy irrigation systems in Monsoon Asia 2002-2006, available at http://www.fao.org/nr/water/espim/tools, accessed 28 October 2010.

[11] Wicaksono, K.P., Prasetyo,A. \& Nakagoshi, N., Performance of Bondoyudo Mayang irrigation system in East Java, Indonesia. Journal of International Development and Cooperation,16(2), pp. 69-80, 2006. 
[12] Santosa, S. \& Susanto,S. et al., Quantitative evaluation model of irrigation performance: case study case study at Sempor and Wadaslintang irrigation system. Paper presented at the 6th Asian Regional Conference of International Commission on Irrigation and Drainage (ICID), 10-16 October 2010, Yogyakarta, Indonesia.

[13] Institute of Irrigation Studies - University of Southampton, U. K., Asset management procedures for irrigation schemes - Preliminary guidelines for the preparation of an asset management plan for irrigation infrastructure, 1995.

[14] Sampath, R.K., Issues in irrigation pricing in developing countries. World Development, 20(7), p. 967. 1992. doi: http://dx.doi.org/10.1016/0305-750X(92)90124-E

[15] Koç, C., Assessing the financial performance of water user associations: a case study at Great Menderes basin, Turkey. Irrigation and Drainage Systems, 21(2), pp. 61-77, 2007. doi: http:// dx.doi.org/10.1007/s10795-006-9015-x

[16] Burton, M., Newcombe, W., et al., Development and application of simplified asset management procedures for transferred irrigation systems. Irrigation and Drainage Systems, 17(1-2), pp. 87-108, 2003. doi: http://dx.doi.org/10.1023/A:1024948717975

[17] Vermillion, D.L., Old and new paradigms for water and development, the Workshop on Water Resources and Irrigation Sector Reform: Principles and Framework of Program Implementation, 2000.

[18] Oad, R., Policy reforms for sustainable irrigation management - A case study of Indonesia. Irrigation and Drainage, 50, pp. 279-294, 2001. doi: http://dx.doi.org/10.1002/ird.28

[19] Gerhard, R.B., Reform of user charges, market pricing and management of water: problem or opportunity for irrigated agriculture?Irrigation and Drainage, 55(1), pp. 1-12, 2006. doi: http://dx.doi.org/10.1002/ird.221

[20] MacDonald, D.H. \& Lamontagne, S. et al., The economics of water: taking full account of first use, reuse, and the return to the environment. Irrigation and Drainage, 54, pp. 93 - 102, 2005. doi: http://dx.doi.org/10.1002/ird.189

[21] Vermillion, D.L. \& Johnson III, S.H., Turnover and irrigation service fee: Indonesia's new policies to achieve economically sustainable irrigation, Irrigation and Drainage Systems, $\mathbf{4}$, pp. 231-247, 1990. doi: http://dx.doi.org/10.1002/ird.189

[22] Australian Asset Management Collaborative Group, Best Practice in Integrated Engineering Asset Management, 2008.

[23] Bank of Indonesia website available at http://www.bi.go.id (accessed 28 April 2013).

[24] Stapelberg, R.F.,. Effects of long-term maintenance and rehabilitation on whole life costs of infrastructure assets. IQPC Conference Paper, Sydney, 2004.

[25] The Directorate General of Water Resources - the Government of IndonesiaParticipatory Irrigation Sector Project (PISP): Project administration memorandum, 2005.

[26] TheGovernment of the Province of Lampung, the Public Works Unit, PISP Implementation Unit, Loan ADB 2064 (SF) - INO/2065 - INO and GON Grant - 4299 Project Report 2008 to 2012, Bandar Lampung, 2013.

[27] Small, L.E., Adriano, M.S. \& Edward, D., Martin, E.M., Final Report: Regional Study on Irrigation Service Fees, Asian Development Bank by the International Irrigation Management Institute: India, 1986.

[28] Shivakoti, G.P. et al., Asian Irrigation in Transition: Responding to Challenges, Irrigation Water Management institute, 2005.

[29] Harrison, M. D., Valuing the Future: Social Discount Rate in Cost-Benefit Analysis, Social Science Research Network: New York, 2010. 